\title{
Cultures of Protest in \\ Transnational ConTEXTS: Indian \\ Seamen Abroad, 1886-1945
}

\author{
Transforming Cultures eJournal, \\ Vol. 3 No 2, November 2008 \\ http://epress.lib.uts.edu.au/journals/TfC
}

\section{Gopalan Balachandran ${ }^{1}$}

Graduate Institute of International Studies, University of Geneva

\begin{abstract}
This paper offers a preliminary exploration of contexts and forms of protest and defiance of authority by Indian seafarers employed on ocean-going steam vessels over six decades to the end of World War II. Though relatively small in numbers and apparently untypical in many respects of a 'modern' industrial workforce, the study of Indian seafarers can shed interesting light on several wider aspects of Indian labour history. The transnational and trans-cultural context of employment of Indian seamen also helps illuminate their subjectivities, knowledges, and agencies in ways that are obscured in more insular histories, while their encounters with bosses and others in authority invite us to re-examine pervasive notions of cultural difference-'owned' as well as attributed.
\end{abstract}

This paper is not about union-led protests, nor about 'everyday' forms of resistance. It dwells instead on a potentially vast and apparently uncharted middle ground of collective resistance by ships' crews. Such resistance, perhaps simmering for weeks at sea, came to head at key moments, usually upon arrival at a foreign port, close to sailing, or when seamen were being transferred from one vessel to another. It could involve, besides the seamen themselves and their ships' officers, a swathe of state agencies including local authorities, the police, and the judiciary, though rarely if ever, unions of local seamen.

On the evidence here, the culture of work and protest of Indian seamen appears to have been informed by a certain rationality-a certain careful weighing of costs, benefits, and opportunities for engagement and disengagement, including through protest-that is altogether at odds with characteristic representations of Calcutta jute workers and British maritime workers enduring similar circumstances or facing similar 'choices'. At the same time this culture was open to modern, secular, and transnational solidarities grounded in universalist values. Paradoxes of this nature demand a sustained effort to recover and re-interpret the complex but immensely creative

\footnotetext{
${ }^{1}$ Gopalan Balachandran is Professor at the Graduate Institute of International Studies at the University of Geneva and works on international economic history, colonialism and development. E-mail: bala@hei.unige.ch, Fax: ++ 41227382904.
} 
subjectivities that Indian workers and seafarers (and needless to add other Asian, African, and Caribbean workers and seamen) developed and articulated within the fluid and liminal spaces they inhabited.

This paper offers a preliminary exploration of contexts and forms of protest and defiance of authority by Indian seafarers employed on ocean-going steam vessels, mainly in the six decades to the end of World War II. Though relatively small in numbers and apparently untypical in many respects of a 'modern' industrial workforce, their study can shed interesting light on several wider aspects of Indian labour history. The transnational and trans-cultural context of employment of Indian seamen helps illuminate their subjectivities, knowledges and agencies in ways that are obscured in more insular histories, while their encounters with bosses and others in authority invite us to re-examine pervasive notions of cultural difference -'owned' or extolled, as well as attributed.

Recognisable unions of Indian seamen arose soon after World War I. Calcutta and Bombay were the principal recruiting ports for Indian seamen and, despite the nervous scepticism of government officials, unions here appear to have been relatively wellorganised affairs. ${ }^{1}$ But they were confined to the recruiting ports, while foreign seamen's unions were, with rare exceptions, indifferent or hostile. ${ }^{2}$ The nature of their work also made it physically impossible for Indian seamen to maintain contact with unions whilst under articles. Thus influential as seamen's unions may have been at the home port, they did not exist in the maritime workplace. Indian seamen had, in consequence, to negotiate their relations with bosses and others on board and at port, without much guidance from unions.

Therefore this paper is not about union-sponsored or union-led protests. Nor is it about 'everyday' forms of resistance at the workplace, about which we still know very little. I focus instead on a potentially vast and apparently uncharted middle ground of collective resistance by ships' crews. Such resistance, perhaps simmering for weeks at sea, came to a head at key moments, usually upon arrival at a foreign port, close to sailing, or when seamen were being transferred from one vessel to another. It could involve, besides the seamen themselves and their ships' officers, a swathe of state agencies

\footnotetext{
${ }^{1}$ For a short history of Indian seamen's unions, especially in Bombay, see Theodore G. Mazarello, Maritime Labour in India (Bombay, 1961), pp. 65-71; also Dinkar Desai, Maritime Labour in India (Bombay, 1940).

2 On the attitude of foreign unions towards Indian seamen, see G. Balachandran, 'Conflicts in the International Maritime Labour Market: British and Indian Seamen, Employers, and the State, 1890-1939', Indian Economic and Social History Review (39, 1, 2002).
} 
including local authorities, the police and the judiciary, though rarely, if ever, unions of local seamen.

This paper is organised as follows. I begin with a somewhat expanded introduction sketching in the background of some features of the employment of Indian merchant seamen relevant to this discussion, and the contexts and constraints affecting their capacity for protest and influencing its modes. The second section briefly recounts the factors promoting the employment of Indian seamen in international merchant shipping during the late-19th century, and outlines the legal and political framework within which the power and authority of ships' masters and officers over them was rendered all but absolute. The third section then attempts to stir back to the surface the insecurities and apprehensions that state and shipping officials hoped to dissolve in their claims of power and authority over Indian seamen. The latter's efforts to improvise opportunities for potential resistance within the elaborate regulations governing their employment are explored next, and finally and briefly, the 1939-40 strikes by Indian seamen.

\section{Bound (and Gagged) by Law and Contract}

The employment of Indian seamen was regulated by merchant shipping acts and regulations laying down procedures for engaging and discharging Indian crews, duration of engagements, the latitudes within which they could sail, procedures for transferring crews between vessels, etc. Regulations also covered issues such as minimum bunk spaces, dietary scales and warm winter clothing. The state was not disinterested in wages but made little direct attempt to regulate them.

All Indian seamen were engaged for a limited period: those on overseas voyages were generally bound by one-year agreements that could be curtailed if the ship returned meanwhile to an Indian port. Extensions, a maximum of twice for periods of three months each, were voluntary, and accompanied by wage increases. Once discharged, they were under no formal obligation to return to the same vessel for a later voyage and were free in principle, though of course not wholly in practice, to choose whether, when, or on which vessel they would sail again. During our period, a majority of Indian seamen had one foot in subsistence agriculture and tended to return to their villages between engagements. At least in the better years, they were believed to be discriminating in their choice of ships and masters, preferring British ships whose laws and practices they were more familiar with, vessels of companies they knew, and officers they had sailed with before. This may have made for some continuity in at least 
one segment of an otherwise apparently casual labour market and encouraged smoother relations at work and informal checks on the behaviour of officers. Indeed, where a vessel had a 'regular' serang, at least some junior officers seem to have regarded him with an attitude akin to respect. ${ }^{3}$

Until the late- $19^{\text {th }}$ century, it was not uncommon for Indian seamen to sign off at familiar foreign ports such as Colombo, Aden and Port Said, to pursue opportunities ashore. Seamen bound for Mecca also relinquished their engagements at Jeddah. Though some officials thought it was 'stretching protection to the point of injury', the Indian government ordered an end to such discharges on the grounds that seamen discharged at foreign ports might turn destitute and become a burden on the state. ${ }^{4}$ Henceforth shipowners could discharge Indian seamen only at ports in British India. Desertions too were punishable by a spell in jail, forfeiture of past wages, a fine and compulsory return to the home port. Consequently, both individually and severally, work on board merchant ships came to resemble a form of indenture for Indian crews. This element of indenture, that could extend for as long as eighteen months, made it important for Indian seamen to get their choice of ship and officers right as far as possible.

Seamen in general, and Indian seamen in particular, laboured under a number of factors limiting their capacity for protest. Most forms of industrial action were regarded as criminal offences on board a vessel even when it was in port. Although the term 'strike' itself has maritime origins, from the late-19th century on, seamen were rarely able to strike work on a ship at sea. The enormous powers states acquired in the $19^{\text {th }}$ century to regulate merchant navies included those to put down strikes by seamen through undisguised repression. Strikes or other kinds of tool-down protests could not only lead to fines but also to prosecution and a jail term for 'wilful disobedience of lawful commands'. Crews walking off vessels were liable to be charged with desertion, while any disorderly or remotely violent form of protest risked being put down as a mutiny. The impact of these limitations on Indian crews' ability to protest was intensified by racial differences and conflicts in the maritime labour market.

\footnotetext{
${ }^{3}$ See for example L.G.W. White, Ships, Coolies, and Rice (London, n.d. but 1936). The 'serang' was the head of the Indian crew of his department. There were three departments - deck, engine-room and saloon - each with its own serang and crew. The saloon existed mainly on passenger vessels. For more about the serang and his relations with the crew, see below.

${ }^{4}$ NAI, GI, FC-SR, Oct. 1883, 1219-41A, especially the note by J. O’Conor, 17 May 1883; also see Jan. 1884, 54-56A; and Legislative Dept., Jan. 1893, proceedings 51-153.
} 
Low wages, poor conditions and the difficulty of effective protest may have driven late$19^{\text {th }}$ century British sailors, particularly in the Eastern, African and Pacific trades, to what even sympathetic contemporary observers described as a state of demoralisation and decline. ${ }^{5}$ The conditions under which Indian seamen worked were worse in almost every respect. The personalised nature of authority on board their ships and the manner in which it was asserted might evoke comparisons with colonial plantations, let alone mills or factories in British India. The habits of authority of the state, shipowners and masters were deeply conditioned to deny any possibility of a reasoned voice to Indian seamen, the laws under which they laboured any possibility of lawful exit.

So how did Indian seamen cope with and against these heavy odds? What did they do when things went wrong for them? Did they protest or resist? What forms did their resistance take?

The forms of resistance of Indian seamen originated in the $19^{\text {th }}$ century, i.e. before trade unions emerged on the scene. Moreover, unlike the authority they encountered, their protest was not arbitrary, 'blind', personalised or violent. On the contrary, the manner in which Indian seamen defied authority appears to have been determined with some care and deliberation.

Also of vital importance in the maritime labour context was the precise authority they chose to defy and, consequently, the site of their actions. Although disputes with other officers were not uncommon, Indian seamen rarely defied the master of their vessel at sea where he embodied not only his own authority as the captain of the ship and the authority of his employers, but also that of the state. Once a ship berthed at a 'home port', however, the master's other powers fell away and he reverted to being a mere manager among many. ${ }^{6}$ Indian seamen thus preferred to bide their time and await the

\footnotetext{
${ }^{5}$ Hood, Blight of Insubordination; for similar views by 'sympathetic' contemporaries, see J.H. Wilson, My Stormy Voyage Through Life (Newcastle, 1925); C.E. Tupper (written by Ernest F. Charles), Seamen's Torch: The Life Story of Captain Edward Tupper, National Union of Seamen (London, n.d. but 1938). Wages of British seamen fell by four to five per cent over 1890-1905, while Britain's per capita national product at current prices rose by over eight per cent: see C.H. Dixon, 'Seamen and the Law: An Examination of Legislation on the British Merchant Seamen's Lot, 1580-1918', unpublished PhD thesis, University College, London, 1981, pp. 233-4; seamen most frequently identified bad food whilst complaining about poor conditions on board. On 'dietary scales' of British seamen, see C.H. Dixon, 'Pound and Pint: Diet in the Merchant Service, 1750-1980', in S. Palmer and G. Williams, eds, Charted and Uncharted Waters (London, 1981), pp. 164-80.

${ }^{6}$ For most purposes, according to international law, a ship was an extension of the territory of the country whose flag it flew and, with some exceptions, the latter's laws took precedence over the laws of countries through whose waters it sailed or at whose ports it called. Apart from ports in Britain, 'home ports' of British vessels included colonial and British Indian ports.
} 
greater space and opportunity for manoeuvre that the dispersal of power at a 'home port' created, before making their protest known. In this they seem to have been different from contemporary European seamen who were believed by employers and shipping officials to have a reputation for mutiny on the high seas.

However, Indian seamen protesting at a 'home port' had also to be alive to the risk of their protest failing and of their having to return to sea at the mercy of a hostile master or officer they may have antagonised in port. Besides, the state was no less powerful or repressive in port for being impersonal, and it had a formidable battery of powers to force agitating seamen back to work or into jail. For all these reasons, not only had the timing and site of resistance to be chosen with care, but also the issue at dispute and the manner in which it was pursued.

\section{Master and Servant}

Indian seamen had long sailed on European, especially East India Company, vessels trading with the sub-continent. With the expansion of oceanic trade and the advent of steam, European merchant vessels began to engage sizeable numbers of Indian seamen from the last quarter of the $19^{\text {th }}$ century. They soon became an impressive presence on British vessels. According to British Board of Trade figures, 24,000 Indian seamen accounted for about a tenth of the employment on British ships in 1891. By 1914 the figures had gone up to 52,000 and $17.5 \%$ respectively. ${ }^{7}$ According to the 1937 Census of Seamen, of the 142,000 working on British vessels, nearly 44,000 (or over 27 percent) were Indians. ${ }^{8}$ By 1952, 150,000 men were said to be employed on British ships, of which Indian seamen made up a quarter. ${ }^{9}$

A major reason for employing Indian seamen was cost. In 1914 their wage was only about a quarter of that of a British seaman. This gap grew wider in subsequent years. It was also much cheaper to provision Indian seamen on board - feeding an Indian seaman again cost only a quarter of what it cost to feed a British seaman, and significantly less than what it cost to feed an Arab or Chinese sailor. Despite differential manning levels

\footnotetext{
${ }^{7}$ C. Dixon, 'Lascars: The Forgotten Seamen', in R. Ommer and G. Panting, eds, The Working Men who Got Wet, (St. Johns', Newfoundland, 1980), p. 281. The 1891 figures classified many Chinese, Malay, and East African seamen as Indian, so the actual increase in the employment of Indian seamen to 1914 would have been more impressive than the above figures.

${ }^{8}$ Cited in the Daily Herald, 24 May 1939.

${ }^{9}$ R. Hope, A New History of British Shipping (London, 1990) pp. 383, 392.
} 
arising from masters seeking safety (and satisfying vanity) through numbers and hiring three - rarely four - Indian seamen to replace two British seamen, employing the former was a certain means of reducing a ship's labour costs.

In addition to lower wages and victualling costs, employers and shipping officials also maintained that European crews were unsuited to Eastern waters where temperatures in ships' stoke-holds could rise to 60 degrees. To be a stoker or fireman on a steamer in the Red Sea. was not 'a white man's job'. ${ }^{10}$ Apart from illness, European seamen were also believed to be more prone to breaking down in hot weather, and turning violent, insubordinate or mutinous.

It was also late- $19^{\text {th }}$ century conventional wisdom among shipowners and officers that British crews were impossible to control. They were so given to drunken and disorderly behaviour that few ships would voluntarily engage their services if seamen of other nationalities could be found. The growth of British seamen's unions from the $1880 \mathrm{~s}$ reinforced fears of disorder and loss of control amidst conditions dictating an ever greater need for order. For example, F.E. Hardcastle, a Marine Surveyor in Bombay, noted that ships carrying British sailors suffered a lot of 'friction and rowdyism culminating in the Police Courts'. 'Timed to hour and tide', mail steamers, in particular, could not afford delays; and shipowners claimed the 'smoother working of the whole internal machinery of a modern steamer' could only be ensured by engaging Indian seamen whenever possible. ${ }^{11}$ Speaking for shipowners, Thomas Sutherland, chairman of the $\mathrm{P} \& \mathrm{O}$, is reported to have complained that it was not 'uncommon' for half the British crew of a vessel to be 'in prison for drunkenness and disobedience.' After experimenting with English sailors and stokers for an year, he said, the $\mathrm{P} \& \mathrm{O}$ decided to employ Indian seamen 'in order to get the work of their ships properly done' ${ }^{12}$ Captain W.H. Hood, author of a polemical essay defending the employment of Indian seamen on British vessels declared that a 'census'

\footnotetext{
${ }^{10}$ Capt. W.H. Hood, The Blight of Insubordination: the Lascar Question and Rights and Wrongs of the British Shipmaster including the Mercantile Marine Committee Report (London, 1903), p. 45; the obverse of the argument about the unsuitability of European seamen in Eastern waters was the strenuous insistence by seamen's unions and many public officials in Britain that Indian seamen were unsuited to the North Atlantic winter. From the late-19th century, restrictions were put on Indian crews sailing to ports on the US North Atlantic seaboard in winters.

${ }^{11}$ NAI, GI, Finance and Commerce Department (FC), Statistics and Commerce Branch (SC), March 1901, 135-42A, p. 50.

${ }^{12}$ Sutherland's letter to the Times, quoted in Hood, Blight of Insubordination, p. 15.
} 
would reveal much that is interesting, in as much as it would show ... how insidiously the Asiatic ocean labourer is displacing the European at his own game, for be he British, French, German, Italian, Austrian, or any other European nationality, he simply cannot compete with, endure and thrive in the same healthy manner as our Aryan brother. All give way to the Asiatic .... ${ }^{13}$

The same author claimed Indian crews were also 'contented with their lot, and amenable to ordinary discipline'. Though 'by ... [no] means angels', they were generally inclined to 'do their work as they should', and were a 'patient and happy' lot. Thanks to the 'complete control' the serang exercised over Indian crews, the latter could 'harmonise more freely than Europeans at similar work, and shift around to help each other in keeping things going' if any one of them fell out from illness or exhaustion. Nor did Indian seamen attempt to regulate work by the clock, and were ready, whenever asked, to change ships as a whole crew. With wages so low, 'the fear of [even] ... small fines' also acted as an 'undoubted incentive to good behaviour'.

For Hood, the employment of Indian crews also meant a restoration of natural order. The larger numbers of men shipped in Indian crews and their easily adaptable ways ensured that officers kept watch instead of taking their coats 'off ... and bustl[ing] about like a bo'sn's mate ....' Moreover, unlike British crews who had little regard for differences of class and station, the 'strongest' factor that made for stable relations between ships' officers and their Indian crews was

the racial difference so well understood by the Indian, when in touch with the Sahib logue [sic!]; the breach is too wide to be easily stepped over, consequently there is all the difference between those who are paid for the purpose of being hewers of wood or drawers of water [sic!] and those who engage for other purposes.

Indian seamen were therefore 'more completely the servants of the shipowner while under engagement than any other group of men doing similar work that shipowners have ever had to do work for them. ${ }^{14}$

At sea as on land, relations between Indian workers and their European officers were largely indirect, and mediated by the serang who was regarded as the 'mainstay' of the

\footnotetext{
${ }^{13}$ Hood, Blight of Insubordination, pp. 10-13.

${ }^{14}$ Hood, Blight of Insubordination, pp. 42-50; similar accounts may also be found in other writings, e.g. L.G.W. White, Ships, Coolies, and Rice (London, n.d., but 1936) .
} 
crew and responsible for its discipline and conduct. The serang was constituted in colonial and shipping discourses as someone holding a traditional position of authority over a crew drawn mainly from his village and bound to him by village-level ties of fealty and subordination. Until about the 1860s, Indian shipping crews tended to be diverse and cosmopolitan. But it seems likely that the maritime labour market at both the recruitment ports, but particularly in Calcutta, thereafter underwent some changes that led to the catchment areas for their crews being concentrated in a small number of regions. This narrowing may have enabled networks of recruitment to become more personalised than had been the case earlier and hence strengthened the role of various intermediaries in the market. Colonial officials often misconstrued the serang as an intermediary. Indeed there is no evidence that the serang and the crew were entrenched in 'traditional' hierarchical relationships on land. ${ }^{15}$

Not much direct information exists about relations between Indian crews and their European officers on board ship. According to some observers, let alone attempting to overcome barriers of language and race to forge direct relations bypassing the serang, few European officers were in a position even to identify their Indian crews. ${ }^{16}$ Hence they had necessarily to give the serang a free hand to manage the crew. Apart from navigational details, ships' logbooks, which are the principal source of information about happenings on board a vessel, record the exceptional rather than the routine. Occasionally, a ship's log might record instances of officers being punished for beating up their Indian crews. But in this case the more noteworthy incident from the point of view of the master of the ship and the log he kept was the punishment meted out to the officer, not the latter's treatment of his victim.

The master-servant laws on which they had been based left a stronger and more enduring stamp on relations between ships' masters and seamen than on employment relations in shore-based industries. ${ }^{17}$ This paper uses the contemporary expression

\footnotetext{
${ }^{15}$ G. Balachandran, 'Searching for the Sardar: The State, Pre-Capitalist Institutions, and Human Agency in the Maritime Labour Market, Calcutta, 1880-1935', in B. Stein and S. Subrahmanyam, eds, Institutions and Economic Change in South Asia (Delhi, 1996), pp. 206-36. For a hypothesis to explain the emergence of 'primordial' ties in the context of the urban labour market, see G. Balachandran, 'Circulation through Seafaring: Indian Seamen, 1890-1945', in Claude Markovits, Claude Pouchepadass, and Sanjay Subrahmanyam, eds, Society and Circulation: Mobile Peoples and Itinerant Cultures in South Asia, 1750-1950 (Delhi, 2003) pp. 89-130.

${ }^{16}$ NAI, GI, Legislative Department, June 1896, 89 A, app. 33, Bombay Shipping Master's letters, nos. 65 and 231 .

${ }^{17}$ For a comprehensive overview of master-servant laws and practices in the British empire, see Douglas Hay and Paul Craven, Masters, Servants, and Magistrates in Britain and the Empire: 1562-1955 (Chapel Hill, 2004).
} 
'master' in preference to the more conventional 'captain' because it reflects more accurately the employment relationship on board a vessel manned by Indian crews. In the case of Indian seamen, restrictions on discharge outside India, that as noted above created conditions of virtual indenture, and an elaborate apparatus of penal sanctions further reinforced the master-servant employment relationship. From the 1880s Indian seamen were also required to possess that classic document of master-servant law and practice - viz. the 'continuous discharge certificate' or CDC - without which employment became progressively more difficult, and from about the 1930s nearly impossible. Though in practice they found several means to evade state and employers' efforts to fix their identities and produce a record of their employment histories that could be used to discipline them, the fear of a 'bad discharge' on their CDCs (or nullies in local parlance) was something Indian seamen could never entirely exclude from their calculations.

Besides penal sanctions, European officers were also known to behave violently with Indian seamen and attempt to violate them in other ways. The state turned a blind eye to all this except when serious injuries resulted or lives were lost. In 1874, ten Indian seamen of the ship Emily Augusta are reported to have died of ill-treatment at the hands of their captain. The latter, 'who always had the name of a brute', was tried for manslaughter and sentenced to fifteen years in jail. ${ }^{18}$ In another incident, the Indian crews of the German steam ship Scharlachberger complained of ill-treatment by the ship's officers, and of one of them falling overboard and drowning to escape the 'illusage of the third engineer' of the vessel. ${ }^{19}$ Similar instances were reported from English ports as well. ${ }^{20}$ According to an official in Rangoon remarking on the Emily Augusta incident, the

arbitrary slapping and cuffing of lascars is ... common enough, not however by men who have sailed long with them, but by young hands fresh from home who seem to think it quite a manly thing to strike a native.

\footnotetext{
${ }^{18} \mathrm{NAI}, \mathrm{GI}, \mathrm{RAC}, \mathrm{CT}-\mathrm{MS}$, June 1877, 9-22A; the quote is from Master Attendant at Akyab to Chief Commissioner, British Burma, 10 Sept. 1875.

${ }^{19}$ NAI, GI, CT-MS, Oct. 1892, 576-87A deals with this incident.

${ }^{20}$ J. Salter, The East in the West or Work among the Asiatics and Africans in London (London, n.d, but 1896), ch. XV; also see NAI, GI, CI-MS, March 1915, 11-24A, representations of C.M. Seal of the Asiatic Seamen's Institute, Birkenhead accompanying the Secretary of State's despatch, 1 May 1914.
} 
Nevertheless, this official insisted, the master should not be denied the power of 'inflicting personal chastisement' on lascars aboard his vessel, for otherwise 'all control ... would be lost'. ${ }^{21}$

As well as the whip, masters also had their book of penalties. Articles of engagement of Indian crews laid down a fairly detailed schedule of fines. Swearing or using improper language and neglecting to bring out and air bedding when ordered could attract half a day's wage as fine. Not returning to ship when leave ran out, insolence towards master or mate, quarrelling, carrying any weapon other than a clasp knife, drunkenness (first offence), not having the crews' meal ready at the appointed time, and defacing the crews' copy of the agreement - any of these charges could mean losing a day's wage. Two days' wages could be docked for failure to be on board at the agreed time, assaulting any person on board or belonging to the ship, and for the second offence of drunkenness. Bringing on board 'spirituous liquors' attracted a fine equal to three days' pay. Sleeping or being negligent while on look out and smoking below deck were both punishable with a full week's wages, while 'secreting contraband goods aboard with intent to smuggle' could cost a seaman his wages for a whole month. In addition, European crews were docked a day's pay for not attending divine service on Sundays, indecorous conduct during service, not being cleaned, shaved and washed on Sundays, and for washing clothes on the Sabbath. ${ }^{22}$

These fines did not exist merely on paper, though to judge from the figures declared to port authorities by masters of British vessels, they do not appear to have been levied to any great extent - Rs 1,200 per year between 1905-6 to 1907-8 in Bombay, and Rs 700 in Calcutta. ${ }^{23}$ Employers also preferred monetary fines to other penalties that were not as easy to enforce. Until the late 1880 s, seamen punished for swearing or drunkenness were docked half a day's rations. But this punishment proved impossible to enforce against Indian crews because their rations went into a common cooking pot, and so had to be replaced by a day's pay as fine. ${ }^{24}$

\footnotetext{
${ }^{21}$ NAI, GI, RAC, CT-MS, June 1877, 9-22A, Superintendent, Mercantile Marine, Rangoon to the Secretary to the Chief Commissioner of British Burma, 17 June 1875; emphasis supplied.

${ }^{22}$ NAI, GI, CI-MS, Aug. 1906, 9-10A, appendix as revised in 1913. For the revisions, see July 1913, 21$31 \mathrm{~A}$.

${ }^{23}$ The annual totals amounted to about 120 months' wages of an ordinary deckhand or fireman at Bombay and 70 months' wages of the same category of workers at Calcutta; for the details, see NAI, GI, CI-MS, Jan. 1909, 3-5A.

${ }^{24}$ See NAI, GI, SC, Oct. 1885, 314-40A.
} 
Employers found monetary fines so convenient that they were loath to give them up for other forms of punishment. Until 1908, seamen were fined for going ashore without leave or 'wilfully disobeying' their officer's ' lawful commands'. Then the rules were changed to require employers to pursue these offences through criminal courts. Though complaining loudly about worsening discipline, few owners bothered to take the trouble or expense to prosecute. Yet their complaints, dutifully echoed by port officials in Bombay and Calcutta, persuaded the government to restore the fines (two days' pay for each day of absence without leave and for each instance of 'wilful disobedience') in 1911. ${ }^{25}$ But in India as elsewhere, the provision for prosecution and jail remained on the statute books.

\section{Spectres of Resistance}

Notwithstanding the regime of lashes and fines assisted by the formidable apparatus of police and magistrate courts, shipowners remained quite nervous of their Indian crews. Narratives produced by employers and the state refer frequently to the supposed ability of the 'lascar' to look after himself. Even Hood, for example, maintained that apart from being 'inscrutable', Indian seamen were not 'easily imposed upon' and could give a great deal of 'trouble and annoyance' not least if they came under the influence of trade unionists in Britain. The Indian seaman, Hood warned, was not 'slow to learn that which he could well do without, and under anything like weak control would soon show signs of the taint if he fancied himself rubbed against the nap. ${ }^{26}$ In a different context, officials of the Bengal government's industries department also spoke of the influence of the 'direct contact of the men ... with western trade unionism', and of their coming to possess 'tickets' entitling them to 'what they call trade-union benefits in England. 27

Images of truculent men determined to protect their interests and resist being imposed upon are as common in employers' and shipping and other government officials' accounts of Indian seamen as those of Hood's 'patient and happy' workers. Such representations could be self-serving, with employers often deploying them to oppose changes in rules and conditions of engagement that might weaken their ability to control Indian seamen. Narratives produced by shipping companies, and often even the state, nevertheless also did tend to apprehend all collective activities of Indian seamen

\footnotetext{
${ }^{25}$ This issue is discussed in NAI, GI, CI-MS, Aug. 1911, 1-3A.

${ }^{26}$ Blight of Insubordination, pp. 54-5.

${ }^{27}$ NAI, GI, CD-LS, June 1922, 1-30 A, note by the Department of Industries, Government of Bengal, September 1921. According to this report the influence dated back to the early years of the $20^{\text {th }}$ century.
} 
through images of resistance. Needless to add, the nature and degree of collective activity of crews differed between sailing vessels and steam ships. But it also differed between steam vessels with European or mixed crews and those employing Indian crews, forcing officers to confront in myriad ways what they believed and sometimes feared to be markers of Indian seamen's collective identities. The racial and cultural divide helped reinforce the class divide between Indian crews and their largely European officers, while their impenetrability to the latter put large spheres of the men's collective activity and consciousness beyond their understanding.

Employers could also not avoid being sensitive to the thin line between group activity and identity of any kind, and workers' unity on the 'shop-floor'. Consequently the ascendancy they sought to establish over their Indian crews was never secure. Employers of Indian seamen, as $19^{\text {th }}$ century employers everywhere, also reacted with alarm to any signs of 'combination'. Already in the 1880 s, employers and shipping officials believed Indian seamen were 'in the habit' of combining and 'dictating terms' on wages and other conditions of engagement. ${ }^{28}$ Trade unions did not become a regular part of Indian seamen's experiences until the interwar years. Yet a sharp-edged fear of Indian seamen ganging up against them was never far from the minds of employers and officials. According to an official writing in the mid-1880s, rules to 'protect lascars from oppression by their masters' were not needed, since they 'formed a union ... quite powerful to protect themselves and their interests'. ${ }^{29}$ Shipowners and officers freely aired similar sentiments and, as racial and class suspicions merged, any pretensions of paternalistic concern evaporated. As the Master Attendant in the Burmese port of Akyab remarked, it was a 'great fault' to regard the lascar as someone 'quite incapable of looking after his own interest'.

Nothing can be a greater mistake: he is far more capable of looking after himself than his brother European seaman, and ... two years' sea-training among mixed crews makes him dangerous if unduly encouraged. ${ }^{30}$

\footnotetext{
${ }^{28}$ Report of the Shipping Master, Bombay, para. 56 in NAI, GI, FC-SC, Oct. 1887, 471-9A.

29 NAI, GI, FC-Separate Revenue Branch (SR), March 1884, 386 A, Officiating Secretary, Board of Revenue, Lower Provinces to Secretary, Government of Bengal, 15 Sept. 1883; also see Commerce and Industry Department (CI), Merchant Shipping Branch (MS), Nov. 1905, 1-11 A.

30 NAI, GI, Revenue, Agriculture, and Commerce Department (RAC), Commerce and Trade Branch (MS), June 1877, 9-22 A, Master Attendant's letter, 10 Sept. 1875; also see SC, Aug. 1893, 178-203A, Shipping Master, Bombay to Secretary, Government of Bombay, 26 Jan. 1893.
} 
Far from being intimidated by their officers, shipping officials noted, not without a sense of wonderment, how the Indian seaman managed to 'hold his own' even against crimps. $^{31}$

Nervousness about 'combinations' and fears about Indian crews' capacity for collective action made employers and officials sensitive to anything that might strengthen the bargaining position of Indian seamen. For example, under certain types of agreements employers were obliged to discharge their Indian crews on 30 June, 31 December, or whenever their ship arrived thereafter at the crew's home port. However, since the mid1880s in Bombay especially, this rule had been observed only in the breach. A new shipping master's efforts to enforce it after nearly two decades of neglect drew strident protests from shipping companies who claimed industrial peace at the port would be shattered if all ships calling near these dates were required to discharge and re-engage crews. They complained of Indian seamen exploiting the resulting excess demand for crews around these dates to 'dictate terms'. According to the British India Steam Navigation Company (BISN) that engaged some crews for its mail boats in Bombay, if after engaging to serve on one vessel crews anticipated securing better terms on another, they 'feigned sickness and declared themselves unfit' to sail, or presented 'unreasonable petitions' including demands for engaging additional hands. Under the present arrangement, the company's agents concluded, the men held the 'whip hand' and were not loath to use it. ${ }^{32}$ Apart from highlighting the troubles faced by the BISN, a local chamber of commerce also pointed to the dangers of having a large number of workers on shore at the same time. It argued that Indian seamen, and particularly those from Goa, were organised into guilds or clubs. ${ }^{33}$ Similar types of organisation 'greatly facilitated strikes in many parts of Europe', and having a 'large number of native seamen adrift in an important port like Bombay' was itself an 'incentive to strikes and other troubles'. Of particular concern to this body was the 'air of ... independence' of the crews, after they had been discharged and paid off. ${ }^{34}$ Clearly shipowners and

\footnotetext{
31 NAI, GI, FC-SR, Oct. 1883, 1219-41A, Acting British Consul at Jeddah to Government of India, Foreign Department, 8 Aug. 1882.

32 NAI, GI, CI-MS, Nov. 1905, 1-11 A, Chamber of Commerce to Government of Bombay, 15 June 1904; agents of BISN to Bombay Chamber of Commerce, 17 July 1905.

33 On Goan clubs, see B.G. D’Souza, Goan Society in Transition: A Study in Social Change (Bombay, 1975), pp. 203-7; the reference to clubs of seamen belonging to other communities was possibly to the loose groupings of seamen living in chummeries in Bombay; for some information on the latter see, the Report of the Indian Sailors' Home Committee, Bombay, in NAI, GI, 46MII/30, July 1932, 1-63 A.

${ }^{34}$ Bombay Chamber of Commerce to the Government of Bombay, 15 June 1904 in NAI, GI, CI-MS, Nov. 1905, 1-11 A; for a similar episode in Calcutta, see SC, March 1885, 1-30A.
} 
shipping officials had little taste for encounters that rudely served to remind them of how tenuous their control over Indian seamen was.

At the end of the day, however, the smug self-assurance that shipowners and bosses cultivated depended on burying any fears and uncertainties in thick pillows of ignorance or dissolving them in racial bravado. For shipowners and officers, moments of doubt and self-questioning were few and far between. The colonial state too remained largely in the dark about most matters relating to Indian merchant seamen. But because it made claims to knowing, to being able to know, and to modes of rule based on knowing, it was often to be found in a tizzy, unable for instance to resolve whether to legislate and make rules for Indian seamen as individual wage workers or as members of a communal collective; whether to base its interventions on the traditional form of collective solidarity that was presumed to exist among Indian crews, or undermine such ties. ${ }^{35}$ But there were limits that even the colonial state dared not cross, so that shipowners were not alone in trying to surround themselves with hardy and familiar certitudes. For instance, nervous about the effects on crew discipline of a diminution of the status of the serang and the crews' 'corporate subservience' to him, government officials in Bengal were as virulently opposed as employers to Indian seamen's efforts to reform recruitment in the $1920 \mathrm{~s}^{36}$

\section{Improvising Custom, Loosening Contract}

Given the regulated nature of maritime employment, the repressive powers of the state and the isolated and disaggregated means of protest Indian seamen had perforce to adopt, it was vital for their success that acts of resistance by Indian seamen be firmly rooted in the law. Lawful protests or attempts at redress were not always easy. For example, should they find conditions on board unsatisfactory, Indian seamen could seek an investigation by port authorities, by a certain proportion of the crew (usually a fifth) lodging a complaint. But sometimes complaints only made more trouble: port officials could be expected to side with ships' officers rather than against them; and crews could be fined for making 'frivolous complaints'. Even complaints that momentarily ruffled bureaucratic apathy and led several months afterwards to procedural refinements might

\footnotetext{
${ }^{35}$ The colonial state's 'knowledge' of maritime matters is discussed in Balachandran, 'Searching for the Sardar', pp. 212-21.

${ }^{36}$ Balachandran, 'Searching for the Sardar', pp. 228-32.
} 
often yield little immediate redress. ${ }^{37}$ Finally, whatever the outcome of a complaint there was always the risk, given the personalised nature of authority on the ship, that the offending crews might be subject to fresh indignities after they returned to sea. Hence, as well as being lawful, it was important for the seamen's own dignity that their protest the resulted in or took the form of exit from the vessel, if not from the engagement.

There were not many ways in which Indian seamen could contrive a lawful termination of their contract ahead of its expiry. But one means of doing so opened up as a result of an informal practice improvised by mutual consent between shipowners and Indian crews, of interpreting a particular clause in the agreements loosely and in a manner that allowed the former to deploy their crews more flexibly and the latter to prolong their engagements. This practice touched the vast majority of Indian crews on British oceangoing vessels who also had at least one opportunity, if not more, to consider it during their engagements. From the latter part of the $19^{\text {th }}$ century Indian seamen appear to have used such opportunities strategically to strengthen their hand vis-à-vis their employers or, as a last resort, as a lawful form of exit from their agreements. As we will see below, the advantage of this practice for Indian seamen depended on it remaining informal. In an indication of their awareness of this precondition, Indian seamen opposed efforts by employers, especially during World War II, to legislate this custom into contract.

According to British and British-Indian mercantile marine laws as they stood at the turn of the century, Indian crews could be transferred from a ship berthed at a port in Britain to another ship berthed at the same port and bound for a port in British India. Both stipulations were observed in the breach: Indian seamen in Britain were frequently transferred from ships which brought them from India to those headed particularly for Australia, USA, and South America. Overland transfers of Indian crews between ports in Britain were frequent, and transfers between European ports were not unknown. Indian seamen did not normally object to these practices because, as pointed out above, they meant longer engagements. Though it meant stretching the law, officials at British ports (known as 'lascar transfer officers') who supervised these transfers were also generally content to follow Indian crews and their employers and allow such transfers.

\footnotetext{
${ }^{37}$ See for example NAI, MS-CI, MS, June 1910m 1-8 A, dealing with the substitution of ghee with margarine in the provisions issued in Buenos Aires to the Indian crew of a Norwegian vessel. Apart from complaining about this when their ship touched port in Britain, the crew also charged the captain with hurting their religious feelings: the captain 'said that we have a baddy religion so please take our notice so that know you for it that he has got nothing to do with the religions [and] the captain [cannot ask anything of us except for] ... his work to be done as he says ...' After several months this complaint led to some minor changes in food inspection procedures. But it made little difference to the crew, who were obliged to return to the vessel and sail under the same master.
} 
Apart from prolonging their engagements, this improvisation signalled Indian seamen's rejection of the paternalism of the state as the latter was reflected in merchant shipping laws. It also gave them an important new leverage with their bosses.

Employers had good reason to welcome even the informal willingness of Indian crews to transfer in Britain from vessels on which they arrived from India, to vessels employed on other trades, because it was so superior to the alternative, viz. employing British crews for the latter and repatriating Indian crews home from Britain. It also made sense for shipping agents at the recruitment port or other managers planning crew logistics to assume such willingness on the part of the Indian crew. In principle there was nothing that prevented them from confirming this assumption with crews before signing them on in India. But this made little practical sense: raising an apparently settled issue would only signal uncertainty and weaken bargaining power, that too in pursuit of an agreement that, however explicit, would remain informal and not be binding on the crews! The resulting silences, and the ambiguity and uncertainty that it opened up in the formal articles of agreement created some ground, should it be warranted by conditions on board the vessel, for a form of lawful resistance by Indian crews or, short of that, for negotiations that might lead to small but significant improvements in their working conditions.

In 1900, the firemen, coal-trimmers and stewards of SS Golconda, berthed in London, refused to transfer to SS Dunera - a troop-ship for which they held a 'strong dislike'. While they could not refuse transfer to a troop-ship, or because they 'disliked' the new vessel, they were within their rights to refuse transfer to the SS Dunera since it was berthed at another port - the troop-ship having dropped anchor at Southampton. The crew's refusal to travel from London to Southampton took port officials at Victoria docks and the Golconda's owners by surprise since 'transfers from port to port' had been 'going on for years'. After the Golconda's owners and port officials failed to persuade the crew members to travel to Southampton, they were charged before a local magistrate for refusal to carry out orders. The offence carried a stiff fine and twelve weeks in jail. Undeterred, the Indian crew reportedly argued that port officials at Victoria docks had no authority to force them to transfer to a ship berthed at another port. Rather unexpectedly for the owners and the officials, the magistrate upheld this argument and discharged the Golconda crew. ${ }^{38}$

\footnotetext{
${ }^{38}$ NAI, GI, FC, SC, Nov. 1900, 354-5B, Superintendent, Mercantile Marine Office to India Office, 25 July 1900, and the India Office reply, 12 Sept. 1900.
} 
Indian seamen were deprived of this possibility of resistance as soon as it was revealed. After the magistrate's ruling the Indian government amended the Merchant Shipping Act to legalise the transfer of Indian crews between UK ports.

The restrictions on transferring them to ships bound for ports other than those in British India, however, offered more enduring possibilities for resistance for Indian seamen seeking to curtail or otherwise renegotiate unsatisfactory engagements. Let me offer two emblematic examples separated by nearly half a century. In February 1885, the crew of SS Speake Hall refused to transfer to the SS Duke of Buckingham on the grounds that the ship would sail to Brisbane before returning to Calcutta or Bombay. According to the local port official at Victoria docks, where both the ships were berthed, this was only an 'excuse'. The crew's real reason for refusing to go on the Duke was that 'they had taken a dislike to some of the officers of the ship'. The magistrate before whom the crew of Speake Hall was produced was anything but sympathetic. He initially threatened the men with six months in jail if they did not sail as ordered, but was forced in the end, by the law and the men's unwavering resistance, to discharge them on grounds of improper transfer. ${ }^{39}$ In another incident, in Glasgow in August 1930, the crew of SS Clan Sinclair refused to transfer to the SS Halesius bound for Buenos Aires because 'they would not go with Capt. Hawley'. The crew, which had accepted discharge from Clan Sinclair in apparent anticipation of the transfer, refused to board the Halesius, preferring instead to spend the night in a shed by the quay. When it still refused to join the new vessel, the crew was arrested on a Saturday, when it was too late to produce it before a Magistrate, and charged with wilful disobedience of the orders of the chief officer of Halesius. A weekend spent in a Scottish prison did little to weaken their resolve. Appearing before the magistrate on Monday, the Indian crew cited the law to argue that the chief officer's order transferring them to the Halesius was unlawful and improper because it was not bound for a port in British India. The Magistrate overruled the contrary interpretation of the law advanced by local port officials, upheld the crew's plea of improper transfer and set them free. ${ }^{40}$

Unlike restrictions on transfer between ports, the latter set of restrictions survived thanks to British shipping unions' opposition to the employment of Indian seamen.

\footnotetext{
${ }^{39}$ NAI, GI, FC-SR, Dec. 1884, 1811-4A, note by A.N.M., 13 April 1885; SC, Oct. 1885, 314-40A, report by H.C. Moore, Superintendent at the Victoria Docks, 25 Feb. 1885. But he also made them go as far as Aden on the Duke to be transferred to a vessel headed for India.

${ }^{40}$ British Library, Oriental and India Office Collections (OIOC), L/E/9/963, Cayzer, Irvine and Co. Ltd. Glasgow, to the India Office, letter, 19 Aug. 1930.
} 
There was little unions could do about the employment of Indian seamen on vessels trading with the sub-continent. But they could and did oppose with great vehemence any moves to expand the sphere of employment of Indian seamen - for example, nearly until World War II, British shipping unions managed to block efforts to relax the winter restrictions on Indian seamen sailing to north Atlantic ports. Shipowners and the colonial state were wary of attempting to codify the informal practice of transferring Indian seamen to ships outside the India trade for fear that the storm of opposition that would break out might put a complete end to such transfers. ${ }^{41}$

During World War II there was growing demand for merchant seamen and a shrinking supply, the latter due to the heightened risk of going to sea and the availability of more job opportunities on land. Indian seamen now increasingly began to use the transfer restrictions in their agreements to refuse sailing to American, African and Australian ports except in exchange for substantial additional wages and benefits. This refusal consequently became an important grievance of shipowners, with the shipping federation (one of the two principal organisations of British shipowners) describing it as 'the greatest danger at the present time' to the smooth operation of the British mercantile marine. Should even one shipowner accept the demand for higher wages, it would be impossible to make Indian crews sail to American and other ports without additional monetary inducement. This was 'bound to lead to trouble'. ${ }^{42}$ Describing the existing restrictions as 'an anachronism' that had defied the long-standing practice of freely transferring Indian crews between ships, the shipping federation and wartime officials of the British government demanded a legislative enactment at least 'as an emergency wartime measure' to force Indian crews to sail to any part of the world from the $\mathrm{UK}^{43}$ But having recently had to deal with a strike by them for higher wages (discussed below), the Indian government had no stomach for 'methods of ... legal compulsion' that would 'infract ... the principle of voluntary choice', anger Indian seamen and cause more disruption to ports and shipping in India. ${ }^{44}$ In the event, wartime transfers of Indian crews in Britain to vessels bound for Africa and America were accompanied by higher wages or bonuses and 'tobacco money'.

\footnotetext{
${ }^{41}$ On this and British shipping unions' attitudes to Indian seamen generally, see Balachandran, 'Conflicts in the International Maritime Labour Market'.

${ }^{42}$ OIOC, L/E/9/977, H.W. Greany, Secretary, Shipping Federation to F.H. Norman, Ministry of Shipping, 27 Dec. 1939.

43 OIOC, L/E/9/977, H.W. Greany, Secretary, Shipping Federation to F.H. Norman, Ministry of Shipping, 27 Dec. 1939; and undated note in file of telephone conversation with Greany.

${ }^{44}$ OIOC, L/E/9/977, Government of India to India Office, telegrams, 6 Feb. and 31 July 1940.
} 
It is instructive, in concluding this section, to elaborate on a point touched upon above: as well as being aware of the laws regulating their employment, Indian seamen's attitudes towards the quality of their engagements were sensitive to the state of the maritime labour market. Since the controversy over engagements (briefly recounted above) was resolved in favour of employers, Indian seamen were bound by one-year agreements. But the provision allowing Indian crews to be discharged in the event of their ship calling at an Indian port before the end of the agreement was retained. During World War I, P\&O ships on the Britain-Australia run began to call at Bombay to deliver mail. Aware of the strong wartime demand for their services, and official and P\&O fears of shipping delays, Indian seamen sought to use such stopovers to discharge themselves and re-negotiate better terms. As a result there were several instances of $\mathrm{P} \& \mathrm{O}$ vessels having to be detained in Bombay to engage new crews, forcing the Indian government to acquiesce in a 'blatantly illegal' notification by the Bombay shipping master (himself a former P\&O official) that a ship could not be deemed to have returned to an Indian port if its stay there did not exceed 48 hours! $!^{45}$ Nor did shipping companies have their way, although Indian seamen consented to voyage to prohibited northern latitudes in winter, when they attempted to negotiate longer-term agreements with Indian crews during World War $\mathrm{I}^{46}$ and in one incident Indian seamen were quick to take advantage of their ship's presence at a US port, where laws were less tilted against seamen than in Britain, to block the shipowner's efforts to extend their agreement. ${ }^{47}$

During the depression, on the other hand, when there was a slump in merchant shipping and Indian seamen faced intense competition from other Asian crews whose engagements were subject to fewer restrictions, they tended to be more flexible about conditions of engagement. For example, in the 1930s many Indian seamen were even willing to forego their right to bonus wages in exchange for longer agreements. ${ }^{48}$

\footnotetext{
${ }^{45}$ See NAI, GI, CI-MS, July 1917, 28-35A, Secretary, Marine Department, Government of Bombay to Secretary, Government of India, letter, 21 Feb. 1917, and Shipping Master, Bombay to the Secretary, Marine Department, Government of Bombay, letter, 3 Jan. 1917.

${ }^{46}$ NAI, GI, CI-MS, July 1917, 28-35A, Ellerman and Bucknall Steamship Co. to Board of Trade, 14 Sept. 1916, enclosed with the Secretary of State's despatch, no. 115-rev., 15 Dec. 1916.

${ }^{47}$ NAI, GI, CI-MS, March 1916, 5-45 (war), report of the British Consul-General in Boston, 17 July 1915.

${ }^{48}$ See NAI, 11 MII (3)/34, April 1935, 1-3B and 11 MII (2)/31, May 1936, 1-41A. The winter restrictions on Indian seamen enhanced the advantages to shipowners of employing Malay and Chinese crews in the 1930s. Many Indian seamen circumvented the restrictions by jumping ship in Singapore and Hong Kong to re-engage on Malay or Chinese articles.
} 


\section{Some Striking Tales from World War II}

Soon after World War I began, there was a short but successful strike for higher wages in Bombay. ${ }^{49}$ The early months of World War II also witnessed successful strikes by Indian seamen on a range of demands, the most important of which was better pay. While recruitment in Bombay and Calcutta was affected, and Indian seamen struck work in ports such as Durban, the majority of the strikes broke out in Britain where hundreds of Indian seamen went to jail - at their peak in November 1939 nearly 400 Indian seamen were serving sentences in British jails for participating in strike actions. ${ }^{50}$ Most of these actions were uncoordinated, yet many lasted several weeks. Nor were the strikes led by established unions of seamen: Indian unions still had a negligible presence overseas; Surat Ali (or Soorat Ally), who was often believed to represent at least Calcutta seamen in Britain, worked alongside the Board of Trade, shipowners and local union bosses to defuse the strikes; while the National Union of Seamen offered little support to the strikers.

More familiar earlier with disaggregated and lawful protest whilst at work, Indian seamen in World War II Britain appear to have been motivated to go on strike as much by a keen sense of opportunity as by their abysmal conditions of work and pay. The opportunity derived from two factors. The first, as already stated, was the tight wartime labour market caused by increased demand and a slowing down of hiring everywhere as seamen paused to digest the new situation. Secondly, in the early months of the war many ships employing Indian seamen were held up for long periods in British ports and shipyards to be refitted for war. As a result, an unusually large number of Indian seamen - almost four thousand according to one estimate - found themselves ashore in Britain. What began as disaggregated actions - initially to refuse or accept conditional transfers except to ships returning to India - soon acquired the dimensions of a widespread strike as crews of several ships threatened or carried out walk-offs around the same time. Though almost all of them asked for wages to be doubled, the strikers made similar rather than uniform demands. Some, such as the crew of the P\&O vessel Somalia, also demanded a war bonus and better food, and went on strike when their request for a religious holiday was turned down; while the eighty-two seafarers of a Bibby Line vessel, which was being converted into a hospital ship, demanded in addition to double

\footnotetext{
${ }^{49}$ Theodore G. Mazarello, Maritime Labour in India (Bombay, 1961), pp. 65-7.

${ }^{50}$ The Daily Worker, 13, 16, and 17 Nov. 1939.
} 
pay, double rations, an eight-hour day, warm clothing and better shoes to compensate for war risks. ${ }^{51}$

The strikes were largely successful. The early strikers, i.e. those who struck work in July and August 1939 and whose ships the Board of Trade (later the Ministry of Shipping, and later still the Ministry of War Transport) in London was keen to send to sea at the earliest, managed to get substantial war bonuses equalling wages. However, by the middle of August the Board of Trade had begun to fear that seemingly isolated and unrelated actions for war risk compensation had developed into a wider strike for higher pay. Officials also began to fear the rising costs to government of employing merchant ships for war. With recruitment in India grinding to a halt, British shipowners agreed towards the end of August to raise Indian crews' wages by 50 per cent. An announcement had already been made in Calcutta when the Board of Trade overruled the hike because it was 'essential in national interests' to 'stabilise prices and cost of living'. An increase in Indian seamen's wages, it declared, would weaken the government's efforts to hold down wages and prices in Britain. ${ }^{52}$ Taking their cue from the government, some shipowners claimed that the strike by Indian seamen for higher pay represented 'profiteering of unskilled British lascar labour of the worst sort. ${ }^{53}$ But as the strikes intensified in Britain and the supply of seamen appeared to dry up in Bombay and Calcutta, the British government was forced to agree to a 25 per cent wage increase in September 1939. This proved insufficient to stem the strikes and another hike of similar magnitude had to be granted two months later. But with many strikers demanding not only more pay but also better food, more tobacco rations or compensation for higher tobacco prices, etc., these strikes continued for several more weeks before subsiding in February $1940 .^{54}$

In July 1942, wages of Indian seamen were raised again to twice those prevailing before the war. This hike followed an increase in the wages of Chinese seamen amidst fears that Indian seamen, who now comprised nearly a third of the British mercantile marine, might once again resort to strikes. In particular, British officials feared strikes at US

\footnotetext{
${ }^{51}$ The Daily Worker, 16 Nov. 1939.

52 PRO, MT 9/3150, M.12623, shipowners' telegram to their agents in Calcutta, 30 Aug. 1939 conceding the wage increase, and 1 Sept. 1939 withdrawing it.

${ }^{53}$ PRO, MT 9/3150, M. 12623, Harold Cayzer of Cayzer Irvine \& Co. (shipowners) to David Margesson, 15 Sept. 1939; emphasis in the original.

54 Public Record Office, London (PRO), MT 9/3150, M. 12623, and MT 9/3150, M. 16782 contains several documents dealing with these strikes; before these strikes, Indian seamen's wages had remained virtually unchanged for nearly 20 years.
} 
ports because US laws gave merchant seamen (regardless of their ship's nationality) more rights than British laws, and British shipowners and the government 'would get no assistance' from the authorities. ${ }^{55}$

It was not only over wages and working conditions that Indian seamen abroad displayed a striking capacity for self-organisation, activity and expression, even in the absence of their regular unions or their local affiliates. In a moving tale of heroic political mobilisation, but so unassuming and patronised that it was all but erased from historical memory, Heather Goodall describes the important role Indian seamen ashore in Australia at the end of World War II played in organising the boycott of ships carrying arms to assist the suppression of the nationalist rebellion and the Dutch re-conquest of Indonesia. ${ }^{56}$ A particularly relevant aspect of this story for this paper is how it neatly reverses roles and stereotypes entrenched in preserved memory - of Australian unions enforcing the boycott and of Indian seamen (when they were not blacklegs) being singularly resistant to modern political mobilisation. But as Goodall explains, though their own accounts claimed complete success, in reality white Australian seamen's and port-workers' unions had failed to stop the ships. In fact, we learn from her paper that workers loyal to local port unions helped load Dutch ships which were only stopped by Indian seamen refusing to work them.

These strikes were led or motivated by a union organised by Indian seamen themselves (who, however, insisted on crucial leadership positions being held at least nominally by Australian unionists in order to maintain the union's continuity). Joining Australian and Indonesian unions in mobilising the Atlantic Charter for their campaign, Indian seamen also developed innovative new strategies of action involving passive and undemonstrative non-cooperation and last minute walk-offs designed to confuse the Dutch and hamper their ability to find replacement crews. Even replacement crews shipped from India by an obliging colonial government ended up on the side of the strikers. Contributing generously to the strike fund and invoking the Atlantic Charter to pursue a successful claim for compensation against the Dutch government-employed shipping contractors, Indian seamen in Australia clearly possessed a strong sense of trans-colonial solidarity, political maturity and organisational ability, besides an all too

\footnotetext{
${ }^{55}$ PRO, MT 9/3657 F. 7724/1942, minute by William Currie, Director, Liner Division of the Ministry of War Transport, 22 June 1942.

56 This paragraph is based on Heather Goodall, 'Port Politics, Race and Change: Indian Seamen, Australian Unions, and Indonesian Independence, 1945-1947', paper delivered at the TransTasman Labour History Conference, Comparative or Transnational?, Auckland University of Technology, February 2007. I am grateful to Professor Goodall for permission to draw from her paper.
} 
astute awareness of themselves and the world around them. This story also offers an extraordinary illustration of the easy and apparently effortless fluidity and courage with which Indian seamen cast off the condescension of employers, officials and Western unions to undertake daunting political journeys, all the while learning from, adapting to and mobilising, expanding and innovating opportunities for solidarity and collective self-expression.

\section{Conclusion}

Historians are often wont to regard Indian workers and peasants as passive victims of tyrannical bosses or inchoate rebels whose protests took 'primitive', 'blind' or 'instinctive' forms of defiance of authority. In another well-known view, forms of working class protest were imitative and mirrored the nature of managerial authority which in India was personalised, excessive and 'bore marks of terror' - and were similarly personalised, vengeful and violent. 'Protesting .. then became a ceremony of defiance' during which the working class 'rebel inverted the terms of his relationship with the manager ... and overturned ... two major everyday signs of his subordination: abusive language and physical violence. ${ }^{57}$

The two views quoted here are both about working class protest. But they evoke stylised descriptions of peasant rebellions. Each account has its analogue in the historiography of peasant protest, so that Calcutta's jute workers may have escaped the fate Parisian crowds suffered at the hands of historians before George Rudé, only to end up as peasant insurgents with their own elementary, 'internal' and imitative logic of protest that is impossible to comprehend through categories used to describe supposedly more universal working class experiences.

In most parts of the world, maritime labour acquired a reputation for militancy in the early part of the $20^{\text {th }}$ century. ${ }^{58}$ However, few historians would give Indian maritime workers high marks either for militancy or proletarian consciousness. ${ }^{59}$ A majority of India's ocean-going seamen came from the same regions as the mill workers of Bombay

\footnotetext{
${ }^{57}$ Dipesh Chakrabarty, Rethinking Working Class History: Bengal, 1890-1940 (Delhi, 1989), pp. 182-4, which also summarises the view the author criticises.

${ }^{58}$ Frank Broeze, 'Militancy and Pragmatism: An International Perspective on Maritime Labour, 18701914', International Review of Social History, XXXVI, 2 (1991), pp. 165-200.

${ }^{59}$ Though arguably, as discussed elsewhere, internationalism may be quite another matter: Balachandran, 'Conflicts in the international maritime labour market'.
} 
and Calcutta and shared their subjective experiences. On balance it is impossible to tell whether these were weakened or reinforced during the long periods they spent at sea and ashore at foreign ports. On the other hand, work on board ships might resemble a form of casual employment even to historians familiar with the regular turnover of labour in Calcutta's jute mills and, to a lesser extent, in the cotton mills of Bombay. A discussion of the historical, ecological, demographic, social and individual contexts and logics that made (or failed to make) workers out of peasants is beyond the scope of this paper. However one understands these processes, it is clear that the nature of their maritime employment was not such as to encourage Indian seamen, had they so wanted, to break any ties they may have had with land; and although their unions challenged this presumption, Indian seamen were commonly believed by officials and others (including ILO representatives) to spend a major part of their working lives on land. ${ }^{60}$ Except to some extent in the deck department, work on board ships also did not require a high degree of skill or prolonged training. Lastly, the nature of maritime employment in India was not conducive to effective trade union activity. Though Indian seamen's unions emerged in the 1920s, they remained confined to the two recruitment ports and did not exist at the workplace (i.e. on board the ship) and at foreign ports.

There is good reason, therefore, to suppose that in almost every respect, the subjective experiences and conditions of Indian seamen were little different from those attributed to Bombay and Calcutta mill workers. Yet chiefly through their own efforts, and despite official and employer opposition, Indian seamen managed to secure some changes in the way they were hired, including the partial elimination of at least one level of intermediaries in their recruitment process. Our knowledge of the 1939-40 strikes by Indian seamen (which cry out to be studied in greater depth) is still limited. But it is evident even from the brief account given above that for the most part these strikes were launched and sustained independently of seamen's unions in the two countries. They lasted over six months despite violent efforts at repression by a powerful imperial state, continued even after wages were raised by 25 per cent in September 1939, and subsided slowly into a truculent peace only after wresting another hike of 25 per cent. Memories of this strike were moreover strong enough even two years later to secure Indian seamen a further increase in wages.

\footnotetext{
${ }^{60}$ On the ILO representative's view, see J. Mowat, Seafarers' Conditions in India and Pakistan (ILO, Geneva, 1949) pp. 8-10; the response of Indian unions to this characterisation is discussed in Balachandran, 'Circulation through Seafaring'.
} 
For the greater part of our period, however, Indian seamen adopted means of protest that, while being collective and resolute, were nevertheless undemonstrative, indeed even undramatic. Often their main objective in these protests was to secure lawful exit from their vessel. It is worth noting here that though this evidence (and research) is far from conclusive, there do not appear to be many instances in the records of Indian crews being lawfully denied discharges sought on grounds of unsatisfactory engagement. ${ }^{61}$ Such success in a situation where the legal, social, political and cultural odds were stacked against them points to a certain familiarity of Indian seamen with the law and with the means of using it to their advantage, to a certain savvy that appears to have been altogether unusual among maritime workers at this time. ${ }^{62}$ It is also useful to underline that this site of protest arose from an informal improvisation in the rules of engagement of Indian seamen. Indian seamen acquiesced in this improvisation because it meant longer engagements. But equally, they seem to have appreciated the leverage this improvisation, and the ambiguity and uncertainty surrounding it, gave them. In this sense, Indian seamen helped create the opening, the very ambiguity, which they could later exploit when the need arose. Although proposals were made during World War II to resolve this ambiguity decisively in favour of employers, they were given up for fear of arousing opposition from Indian seamen.

Lacking the militancy of strikes or the drama of violent carnival-type protests, the mainly undemonstrative protests discussed above are easily obscured. But they are of some significance both to maritime and Indian working class history, the latter as there is a tendency among historians to assume that Indian workers were victims of an 'original' mentality and a workplace culture that allowed little room for the norms of bourgeois legality.

Mercantile marine laws were loaded against seamen, more so, in the name of paternalism, against those from India. Yet Indian seamen contrived lawful means of protest in circumstances where recourse to violence or 'mutiny' might appear more natural and legitimate, even perhaps, as many British crews showed, inevitable. There were several factors that might have predisposed Indian crews to individual or

\footnotetext{
${ }^{61}$ Crews on board S.S. Scharlachberger calling at London complained of 'ill-usage' by their officers and refused to return to work. But they were forcibly returned to the vessel by the local port and judicial authorities because the ship flew a German flag. The crews earlier protests to port authorities in Hamburg had led to nothing because the men neither knew German nor were they familiar with German legal procedures. On this incident see NAI, GI, CT-MS, Oct. 1892, 576-87A.

62 The British police also appear to have been frustrated by Indian seamen's knowledge of British shipping laws dealing with desertion: see OIOC, L/E/9/962, CID officer J. Lawson's Report to the Chief Constable, 26 Nov. 1930.
} 
collective violence. Authority on ships was highly personalised, it was marked by violence and, finally, the men had few lawful means of resisting their bosses ashore and none whatever afloat. Nor did they have the option of exit. Yet there is no evidence, at least thus far in my research (focussed on the period after the mid-19th century), of protests by Indian seamen turning 'personalised', 'vengeful' or 'violent' manifestations of resistance that in the maritime context were associated with mutinies. Despite grave provocations, even the strikes of 1939-40 were remarkably free from violence by Indian seamen. Mutinies may have worked in certain circumstances on $18^{\text {th }}$ century sailing vessels. But they were clearly unsustainable in the more regulated late19th century steam environment, particularly on British vessels. The balance of power was unambiguously in favour of employers and the state, especially the British imperial state whose extensive reach meant its immense resources could quickly be placed at the command of a threatened ship's captain. Consequently the costs to participants of mutinies threatened to dwarf any gains they might make. These asymmetries of power were further reinforced for Indian seamen by their position as imperial subjects and by the hostile attitude of British maritime unions. Unlike British seamen, who continued to 'mutiny' (in the form the term came by then to be interpreted) until almost the turn of the $20^{\text {th }}$ century, Indian seamen appear to have developed an almost instinctive and early appreciation of these realities.

It might be argued that Indian seamen did not mutiny because they lacked a 'tradition' of mutiny. But to make this argument is to unreflexively invoke an almost mystical and historically stable realm of maritime working class militancy that, if its historical stability and continuity were (problematically) to be assumed, was as exclusive along one axis as it was democratic, republican and inclusive along another. ${ }^{63}$ To these neglected discontinuities in time we may add seeming parallels between apparently dissimilar contexts: after all, Calcutta jute workers were not unfamiliar with forms of protest that in a late-19th century maritime context would be classified as mutiny - i.e. collective violent insubordination. Yet why were these forms of protest (whether or not we wish to call them mutinies) not reproduced on ships? Equally, what tradition can we invoke to explain the legally embedded forms of resistance Indian seamen contrived to secure a termination of their articles when they felt such exit was necessary for their wellbeing or their dignity?

\footnotetext{
${ }^{63}$ On $18^{\text {th }}$ century maritime working class militancy, see Marcus Rediker, Between the Devil and the Deep Blue Sea: Merchant Seamen, Pirates, and the Anglo-American Maritime World, 1700-1750 (New York, 1993) and Peter Linebaugh and Marcus Rediker, The Many-Headed Hydra: Sailors, Slaves, Commoners, and the Hidden History of the Revolutionary Atlantic (Boston, 2000).
} 
Clearly, not only the forms of resistance but also the general disposition of Indian seamen towards their work and their bosses differed from those conventionally attributed to Calcutta jute workers and British maritime workers. The culture of work and protest of Indian seamen appears to have been informed by a certain rationality - a certain careful weighing of costs, benefits and opportunities for engagement and disengagement, including through protest - that is altogether at odds with characteristic representations of Calcutta jute workers and British maritime workers enduring similar circumstances or facing similar 'choices'. Nor was this culture, as the story of the Australian strikes of 1945-47 illustrates, closed to modern, non-sectarian and transnational solidarities grounded in universalist values. Paradoxes of this nature demand a sustained effort to recover and re-interpret the complex, fluid and immensely creative subjectivities that Indian workers and seamen (and needless to add other Asian, African and Caribbean workers and seamen) developed and articulated in the liminal and shifting spaces they inhabited. They also behove us to reconsider the multiple condescensions in which historians hold non-Western workers as well as the universalist norms against which they are held to fail. The alternative is not merely a significant erasure of historical memory but also the further entrenchment of attitudes and habits of thought that render such erasures unknowable and irrecoverable.

\section{References}

Balachandran, G. (1996) 'Searching for the Sardar: The State, Pre-Capitalist Institutions, and Human Agency in the Maritime Labour Market, Calcutta, 18801935', in B. Stein \& S. Subrahmanyam (eds.) Institutions and Economic Change in South Asia, Delhi, pp. 206-36.

Balachandran, G. (2002) 'Conflicts in the International Maritime Labour Market: British and Indian Seamen, Employers, and the State, 1890-1939', Indian Economic and Social History Review, 39, 1.

Balachandran, G. (2003) 'Circulation through Seafaring: Indian Seamen, 1890-1945', in Claude Markovits, Claude Pouchepadass, \& Sanjay Subrahmanyam (eds.) Society and Circulation: Mobile Peoples and Itinerant Cultures in South Asia, 1750-1950, Delhi, pp. 89-130.

Broeze, Frank (1991) 'Militancy and Pragmatism: An International Perspective on Maritime Labour, 1870-1914', International Review of Social History, XXXVI, 2, pp. 165-200.

Chakrabarty, Dipesh (1989) Rethinking Working Class History: Bengal, 1890-1940, Delhi.

D’Souza, B.G. (1975) Goan Society in Transition: A Study in Social Change, Bombay.

Daily Herald, 24 May 1939. 
Daily Worker, The 13, 16, and 17 Nov. 1939.

Daily Worker, The 16 Nov. 1939.

Desai, Dinkar (1940) Maritime Labour in India, Bombay.

Dixon, C. (1980) 'Lascars: The Forgotten Seamen', in R. Ommer and G. Panting (eds.) The Working Men who Got Wet, St. Johns', Newfoundland.

Dixon, C.H. (1981) 'Pound and Pint: Diet in the Merchant Service, 1750-1980', in S. Palmer and G. Williams (eds.) Charted and Uncharted Waters, London, pp. 16480.

Dixon, C.H. (1981) 'Seamen and the Law: An Examination of Legislation on the British Merchant Seamen's Lot, 1580-1918', unpublished PhD thesis, University College, London.

Goodall, Heather (2007) 'Port Politics, Race and Change: Indian Seamen, Australian Unions, and Indonesian Independence, 1945-1947', paper delivered at the TransTasman Labour History Conference, Comparative or Transnational?, Auckland University of Technology, February 2007.

Hay, Douglas \& Craven, Paul (2004) Masters, Servants, and Magistrates in Britain and the Empire: 1562-1955, Chapel Hill.

Hood, Capt. W.H. (1903) The Blight of Insubordination: the Lascar Question and Rights and Wrongs of the British Shipmaster including the Mercantile Marine Committee Report, London.

Hope, R. (1990) A New History of British Shipping, London.

Linebaugh, Peter \& Rediker, Marcus (2000) The Many-Headed Hydra: Sailors, Slaves, Commoners, and the Hidden History of the Revolutionary Atlantic, Boston.

Mazarello, Theodore G. (1961) Maritime Labour in India, Bombay.

Mowat, J. (1949) Seafarers' Conditions in India and Pakistan, ILO, Geneva

Rediker, Marcus (1993) Between the Devil and the Deep Blue Sea: Merchant Seamen, Pirates, and the Anglo-American Maritime World, 1700-1750, New York.

Salter, J. (n.d. but 1896) The East in the West or Work among the Asiatics and Africans in London, London.

Tupper, C.E. (written by Ernest F. Charles), (n.d. but 1938) Seamen's Torch: The Life Story of Captain Edward Tupper, National Union of Seamen, London.

White, L.G.W. (n.d. but 1936) Ships, Coolies, and Rice, London.

Wilson, J.H. (1925) My Stormy Voyage Through Life, Newcastle.

\section{Archival Sources}

National Archives of India (NAI):

NAI, 11 MII (3)/34, April 1935, 1-3B and 11 MII (2)/31, May 1936, 1-41A.

NAI, MS-CI, Nov. 1905, 1-11 A.

NAI, MS-CI, MS, June 1910m 1-8 A. 
NAI, GI, CI-MS, Nov. 1905, 1-11 A; SC, March 1885, 1-30A, Bombay Chamber of Commerce to the Government of Bombay, 15 June 1904.

NAI, GI, 46MII/30, July 1932, 1-63 A.

NAI, GI, CD-LS, June 1922, 1-30

NAI, GI, CI-MS, Aug. 1906, 9-10A, appendix as revised in 1913. For the revisions, see July 1913, 21-31A.

NAI, GI, CI-MS, Aug. 1911, 1-3A.

NAI, GI, CI-MS, Jan. 1909, 3-5A.

NAI, GI, CI-MS, July 1917, 28-35A, Ellerman and Bucknall Steamship Co. to Board of Trade, 14 Sept. 1916, enclosed with the Secretary of State's despatch, no. 115rev., 15 Dec. 1916.

NAI, GI, CI-MS, July 1917, 28-35A, Secretary, Marine Department, Government of Bombay to Secretary, Government of India, letter, 21 Feb. 1917, and Shipping Master, Bombay to the Secretary, Marine Department, Government of Bombay, letter, 3 Jan. 1917.

NAI, GI, CI-MS, March 1915, 11-24A, representations of C.M. Seal of the Asiatic Seamen's Institute, Birkenhead accompanying the Secretary of State's despatch, 1 May 1914.

NAI, GI, CI-MS, March 1916, 5-45 (war), report of the British Consul-General in Boston, 17 July 1915.

NAI, GI, CI-MS, Nov. 1905, 1-11 A, Chamber of Commerce to Government of Bombay, 15 June 1904; agents of BISN to Bombay Chamber of Commerce, 17 July 1905.

NAI, GI, CT-MS, Oct. 1892, 576-87A.

NAI, GI, FC, SC, Nov. 1900, 354-5B, Superintendent, Mercantile Marine Office to India Office, 25 July 1900, and the India Office reply, 12 Sept. 1900.

NAI, GI, FC-SC, Oct. 1887, 471-9A.

NAI, GI, FC-Separate Revenue Branch (SR), March 1884, 386 A, Officiating Secretary, Board of Revenue, Lower Provinces to Secretary, Government of Bengal, 15 Sept. 1883;

NAI, GI, FC-SR, Dec. 1884, 1811-4A, note by A.N.M., 13 April 1885; SC, Oct. 1885, 314-40A, report by H.C. Moore, Superintendent at the Victoria Docks, 25 Feb. 1885.

NAI, GI, FC-SR, Oct. 1883, 1219-41A, Acting British Consul at Jeddah to Government of India, Foreign Department, 8 Aug. 1882.

NAI, GI, FC-SR, Oct. 1883, 1219-41A, especially the note by J. O'Conor, 17 May 1883; also see Jan. 1884, 54-56A; and Legislative Dept., Jan. 1893, proceedings 51-153.

NAI, GI, Finance and Commerce Department (FC), Statistics and Commerce Branch (SC), March 1901, 135-42A, p. 50.

NAI, GI, Legislative Department, June 1896, 89 A, app. 33, Bombay Shipping Master's letters, nos. 65 and 231. 
NAI, GI, RAC, CT-MS, June 1877, 9-22A, Superintendent, Mercantile Marine, Rangoon to the Secretary to the Chief Commissioner of British Burma, 17 June 1875; emphasis supplied.

NAI, GI, RAC, CT-MS, June 1877, 9-22A; the quote is from Master Attendant at Akyab to Chief Commissioner, British Burma, 10 Sept. 1875.

NAI, GI, Revenue, Agriculture, and Commerce Department (RAC), Commerce and Trade Branch (MS), June 1877, 9-22 A, Master Attendant's letter, 10 Sept. 1875; also see SC, Aug. 1893, 178-203A, Shipping Master, Bombay to Secretary, Government of Bombay, 26 Jan. 1893.

NAI, GI, SC, Oct. 1885, 314-40A.

British Library, Oriental and India Office Collections (OIOC):

OIOC, L/E/9/963, Cayzer, Irvine and Co. Ltd. Glasgow, to the India Office, letter, 19 Aug. 1930.

OIOC, L/E/9/962, CID officer J. Lawson's Report to the Chief Constable, 26 Nov. 1930.

OIOC, L/E/9/977, Government of India to India Office, telegrams, 6 Feb. and 31 July 1940.

OIOC, L/E/9/977, H.W. Greany, Secretary, Shipping Federation to F.H. Norman, Ministry of Shipping, 27 Dec. 1939.

Public Record Office, London (PRO):

PRO, MT 9/3150, M. 12623, and MT 9/3150, M. 16782

PRO, MT 9/3150, M. 12623, Harold Cayzer of Cayzer Irvine \& Co. (shipowners) to David Margesson, 15 Sept. 1939; emphasis in the original.

PRO, MT 9/3150, M.12623, shipowners' telegram to their agents in Calcutta, 30 Aug. 1939 conceding the wage increase, and 1 Sept. 1939 withdrawing it.

PRO, MT 9/3657 F. 7724/1942, minute by William Currie, Director, Liner Division of the Ministry of War Transport, 22 June 1942. 